\title{
«Отдельная типа республичка»: структурные особенности пространственно изолированных локальных сельских сообществ ${ }^{1}$
}

\author{
А.А. ПОЗАНЕНКО*
}

\begin{abstract}
*Артемий Алексеевич Позаненко - аналитик, проектно-учебная лаборатория муниципального управления, Национальный исследовательский университет «Высшая школа экономики»; преподаватель, кафедра местного самоуправления, Департамент государственного и муниципального управления, факультет социальных наук, Национальный исследовательский университет «Высшая школа экономики». Адрес: 101000, Москва, ул. Мясницкая, д. 20. E-mail: apozanenko@hse.ru

Цитирование: Позаненко А.А. (2018) «Отдельная типа республичка»: структурные особенности пространственно изолированных локальных сельских сообществ // Мир России. Т. 27. № 4. С. 31-55. DOI: 10.17323/1811-038X-2018-27-4-31-55
\end{abstract}

На севере России расположено значительное число сельских населенных пунктов, транспортное сообщение которых с внешним миром затруднено или в привычном понимании отсутствует, из-за чего многие деревни, села и поселки оказываются в пространственной изоляции. Обусловлена такая ситуация, с одной стороны, сжатием в провинции системы общественного транспорта, а с другой стороны, моночентричностью организации дорожной сети как на уровне страны в целом, так и на уровне регионов и районов. Существуюшие описания соииальной структуры современной российской северной деревни сделаны преимущественно по результатам обследований обычных, неизолированных населенных пунктов. В статье предпринимается попытка восполнить эту лакуну и выявить структурные особенности пространственно изолированных локальных сельских сообществ. Эмпирическую базу исследования составили материаль, полученные автором в 15 труднодоступных населенных пунктах 5 регионов европейской части России. Материаль собраны методами глубинного интервью (взято 63 интервью с местными жителями и 5 с внешними экспертами) и наблюдения, в том числе включенного.

\footnotetext{
1 Статья подготовлена по результатам исследовательского проекта «Социальная структура локальных сообществ, пространственно изолированных от институтов публичной власти» (при финансовой поддержке Фонда «Хамовники», 2012-2014). Автор выражает благодарность В.А. Соколову за участие в экспедиции по р. Мезени и Н.Н. Жидкевич за советы по конструированию текста.
} 
Исследование показывает, что изолированные сообщества по своей структуре отличны от обычного сельского Нечерноземья. Их демографический состав в иелом схож с составом аналогичных неизолированных сообществ, однако в ряде случаев в значительной изоляции наблюдается относительно низкий средний возраст населения (выше доля детей и молодыlх). Обитатели труднодоступных деревень выделяются образом жизни, в том числе стратегиями получения средств к существованию, экологическим поведением, организацией хозяйствования. Изоляция обеспечивает местному населению ряд преимуществ, основным из которых можно считать отсутствие взаимодействия с контролирующими и опекающими органами власти. Отсутствие контроля позволяет жителям пользоваться наиболее доступными, эффективными и благоприятными для себя и сообщества способами получения средств к существованию, преимущественно теневыми и ориентированными на присвоение природньх ресурсов; отсутствие помощи, в свою очередь, стимулирует взаимную поддержку и самоорганизацию, что позволяет оперативно и успешно решать частные и общие вопросы. Эти преимущества положительно влияют на самодостаточность и жизнеспособность труднодоступных сообществ.

Ключевые слова: пространственная изоляция, транспортная доступность, российское село, социальная структура села, теневая экономика, присваивающая экономика, местное самоуправление

В России существуют сотни деревень, сел и поселков, в силу исторических и географических обстоятельств отрезанных от «большой земли», в том числе от своих районных центров. Их пространственная изоляция обусловлена в первую очередь произошедшим в 1990-е гг. сжатием системы провинциального общественного транспорта, особенно водного и малой авиации. В европейской России этот вид сообщения практически исчез [Ильин 2010], а там, где какие-либо маршруты все же остались, многократно увеличилась стоимость проезда.

В некоторых местах транспортная труднодоступность усиливается вследствие особого устройства российской дорожной сети. Села, как правило, хорошо связаны с районным центром, районы - с региональным центром, а региональные - с Москвой, тогда как горизонтальные связи развиты крайне слабо, а часто и вовсе отсутствуют [Родоман 2006; Каганский 2011]. Поэтому в пространственной изоляции оказываются многие деревни, расположенные на территориях, прилегающих к региональным и даже муниципальным границам. Яркий пример - граница Костромской области с Вологодской, Кировской и Нижегородской областями. Каждая из этих весьма протяженных границ пересекается автомобильной дорогой с твердым покрытием лишь единожды. При этом по обеим ее сторонам находятся населенные пункты, стоящие вдали от транспортных магистралей и своих районных центров; добраться до них можно только по труднопреодолимым проселочным дорогам, по которым общественный транспорт не ходит. Пространственно изолированные населенные пункты - явление, наиболее характерное для Севера России; в некоторых его районах, где низка заселенность и слабо развита дорожная сеть, таких сел и деревень большинство, а их жители составляют значительную долю населения района.

Существующие описания современной российской нечерноземной сельской местности сделаны преимущественно на основе исследований, реализован- 
ных в населенных пунктах, транспортное сообщение с которыми не затруднено [Морозова 2008; Нефедова 2008; Никулин, Никулина 2015; Аверкиева 2016]. Однако фактор изоляции должен тем или иным образом влиять на характеристики локальных сообществ, и изучение таких сообществ стало одной из задач настоящего исследования, целью которого было выявление влияния разного рода изоляции на социальную структуру (в широком смысле понятия) ${ }^{2}$. Изолированными было решено считать деревни, села и поселки, из которых проблематично добраться даже до районного центра. С другой стороны, не рассматривались места, куда можно круглогодично и ежедневно добраться личным или общественным транспортом, а также военные городки, вахтовые поселки при месторождениях, кордоны в заповедниках и прочие ведомственные объекты, существование которых зависит от политики организаций, в структуру которых они входят.

Обследовано 15 пространственно изолированных локальных сообществ в 5 регионах европейской России: Карелии (2 старые поморских деревни на берегу Белого моря), Коми (2 старые деревни и село на реке Мезени), Архангельской (4 старые деревни и село на Мезени), Костромской (3 поселка советского периода при уже исчезнувших лесопунктах, а также старое село и куст деревень вокруг него) и Мурманской (оленеводческое село, основанное во времена НЭПа) областях. В наименьшем из обследованных населенных пунктов постоянно проживает 17 чел., в наибольшем - примерно 400. Изученные сообщества схожи в этноконфессиональном отношении (в некоторых селах, помимо русских, живут коми, ненцы, саамы, но степень их «обрусения» позволяет пренебречь этим фактом). Наименее изолированным оказался поселок, расположенный всего в одном километре от районного центра, но отделенный от него рекой без моста и парома. Наиболее изолированным стало село, удаленное от ближайшей дороги на 120 км по воздуху; летом туда можно добраться только вертолетом, который летает из районного центра раз в неделю, но билет в одну сторону по состоянию на лето 2013 г. стоил примерно 2,5 тыс. руб., поэтому жители пользуются вертолетом в среднем раз в год; зимой открывается поддерживаемый самими жителями тракторно-вездеходный и снегоходный путь по тундре, замерзшим болотам и озерам (на автомобиле и даже внедорожнике туда доехать нельзя). При этом в данное село, пусть и дорого и всего раз в неделю, но можно долететь круглый год, а есть в выборке населенные пункты, куда, как правило, добраться легче, но они могут быть полностью отрезаны по месяцу и более из-за ледохода, ледостава или половодья.

Уровень изоляции определялся по стартовым условиям, в которых локальные сообщества оказались в результате не зависевшего от них снижения транспортной доступности, которое произошло либо из-за закрытия селообразующего предприятия и исчезновения соответствующего транспорта и техники, либо изза ликвидации, урезания или многократного удорожания сообщения общественным транспортом. Действия, которые местные жители предпринимают для того, чтобы приспособиться к новым условиям, при определении уровня изоляции не учитывались.

Исследование проводилось по месту проживания информантов методами глубинного интервью и наблюдения, в том числе с элементами включенного

2 Объектом исследования были также самоизолирующиеся сообщества и сообщества, оказавшиеся удаленными от институтов публичной власти в результате оптимизации органов местного самоуправления. 
наблюдения (63 интервью с 85 местными жителями, около 75 бесед, не выделенных в отдельные интервью, 4 интервью с сотрудниками администраций сельских поселений и еще одно с местным жителем, хорошо знакомым с предметом исследования).

\section{Демографические особенности сообществ}

По своей половозрастной структуре обследованные сообщества мало отличаются от обычных нечерноземных сельских сообществ: значительную долю населения составляют пенсионеры; людей в трудоспособном возрасте насчитывается столько же или чуть меньше, дети отсутствуют вовсе или их немного. Впрочем, есть несколько примечательных случаев: заметно выделяется самая удаленная из архангельских деревень - дети здесь составляют не менее десятой части населения; интересен и наиболее изолированный из костромских поселков, где в результате беби-бума, произошедшего в начале 1960-х гг., в настоящее время преобладают люди среднего возраста, также есть старые люди (их родители), а пожилых в возрасте 60-70 лет практически нет. Наконец, особняком стоит мурманское село, в котором из 400 жителей примерно 70 - дети; пенсионеры здесь составляют не более трети, а численность населения после распада СССР упала незначительно (в неизолированном непригородном Нечерноземье это был бы небывалый случай). В это село продолжают переезжать с «большой земли»к мужу или жене либо на объявленную вакансию, в том числе и из других регионов, поскольку здесь, благодаря северным надбавкам, относительно высокая для периферии зарплата. Таким образом, в ряде случаев в значительной изоляции наблюдается относительно низкий средний возраст населения. В этом плане показателен также пример мезенских деревень: в лешуконском (Архангельская область) и удорском (Коми) Помезенье процессы депопуляции и старения по мере удаления населенных пунктов от районных центров (и усиления труднодоступности) несколько замедляются - об этом говорят как наблюдения, так и статистические данные 3 .

Летом численность местного населения увеличивается (в некоторых маленьких деревнях многократно) за счет приезжающих родственников и дачников, которые в пространственно изолированных населенных пунктах, если вообще есть, то почти всегда являются исключительно бывшими «своими», т.е. местными уроженцами, приезжающими в родительские дома. Сторонние дачники отсутствуют как ввиду специфики транспортного сообщения и чрезмерной экзотичности подобного отдыха, так и из-за того, что зачастую свободных участков нет, а у опустевших и даже разрушенных домов есть наследники, не желающие продавать свое родовое гнездо.

Замкнутостью обусловлено и то, что в старых деревнях и селах практически все друг другу приходятся родственниками.

\footnotetext{
3 Сопоставление этих деревень допустимо вследствие сходства их экономической специализации, состава и образа жизни населения. Они расположены вдоль одной реки, что позволяет легко проследить различия в степени пространственной изоляции: чем дальше от районного центра, тем труднодоступнее.
} 
«Нас в школе заставили составить дерево родословное [составили до седьмого колена], дак бабушка мне такую родню нашла, что мне все учителя в школе родственниками стали» ${ }^{4}$.

До революции церковь следила за недопущением кровосмешения; в советское время на это перестали обращать внимание, зато возник некоторый поток людей со стороны. Сейчас же нет ни контроля, ни, как правило, притока населения, и поэтому, по словам одного из информантов, бывает, что женятся кровные родственники, в том числе двоюродные братья и сестры.

«У нас в деревнях очень много народу сходятся с троюродными братьями и сестрами. Я встречалась 2 года с троюродным братом, а то, что мы троюродные, узнали только в этом году. Ну, мне кажется, если любовь взаимная, то почему бы не согласиться, ведь в этом ничего такого нету» 5 .

\section{Стратегии получения средств к существованию}

Как показывают наблюдения, выбирая способы получения средств к существованию, жители пространственно изолированных сел ориентируются не на максимизацию дохода, а на то, чтобы эти способы не вызвали недовольства сообщества [Sherman 2006]. В то же время община, обеспечивая своим членам право на жизнь, к эгалитаризму не стремится [Scott 1976]. Таким образом, члены сообщества, достигшие большего материального благополучия, не порицаются, если не нарушают неписаных общинных правил. При этом ограниченность возможностей заработка приводит к тому, что расслоение по уровню жизни здесь, хотя и присутствует, но не бывает слишком значительным. Как правило, жители одного населенного пункта в большинстве своем имеют близкие профессии: в лесопункте - лесозаготовители, в поморских деревнях - рыбаки, в тундре - оленеводы и т.д. Селообразующего предприятия может уже и не быть, но профессии остались. Тем не менее люди к ним не привязаны: местная экономика и жизнь устроены таким образом, что желающий может приспособиться практически к любой работе.

Сколь-либо значимые внебюджетные работодатели есть в двух обследованных населенных пунктах: это сельскохозяйственный производственный кооператив (СПК) в коми селе (менее 30 работников при населении примерно в 200 чел.) и оленеводческий кооператив в мурманском селе (около 50 работников, еще около 20 чел. работают в двух отделившихся от кооператива организациях). В обоих селах количество официальных рабочих мест значительно превышает половину численности трудоспособного населения; еще в двух крупных населенных пунктах рабочих мест в два раза меньше, чем трудоспособного населения; в остальных одиннадцати, в которых реально проживает от 17 до 100 чел., численность трудоспособного населения превышает количество рабочих мест в несколько раз

\footnotetext{
4 Студентка ССУЗа, 18 лет, Архангельская область, сентябрь 2014 г. (постэкспедиционное интервью в социальной сети).

5 Студентка ССУЗа, 18 лет, Архангельская область, сентябрь 2014 г. (постэкспедиционное интервью в социальной сети).
} 
(например, 7 мест на 50 чел. в трудоспособном возрасте, 1 - на 10, 3 - на 20), причем некоторые места заняты пенсионерами. Обычный набор официально трудоустроенных - продавец, почтальон, фельдшер, директор (и, как правило, единственный сотрудник) Дома культуры. При этом в некоторых селах нет ни одного из перечисленных работников, в других - только продавец, еще где-то к этому набору может добавляться либо специалист администрации, либо санитарка в фельдшерско-акушерском пункте, либо еще один продавец, социальный работник, кочегар, связист, дизелист и другие. Таким образом, в пространственной изоляции ситуация с официальными рабочими местами в целом складывается так же, как в обычной сельской местности.

Открывать и оформлять собственное дело здесь, как правило, нерационально. Это связано как с трудностями и дороговизной ведения бизнеса и сбыта продукции, так и с бюрократической необходимостью регулярно ездить в районный центр. Если не считать трех сельскохозяйственных кооперативов, существующих с советского времени, то весь местный бизнес в обследованных населенных пунктах представлен фермерским хозяйством, пилорамой, несколькими оформившими предпринимательство рыбаками и магазинами (основной официальный бизнес периферии), большинство которых принадлежат либо «частникам» (обычно сторонним предпринимателям из районного центра), либо райпо или районному ООО (эти магазины местные по-прежнему называют «государственными»).

Пространственная изоляция не позволяет местным жителям трудиться в режиме маятниковой миграции, и даже отходничество (регулярные выезды на работу на продолжительный срок) [Плюснин, Заусаева, Жидкевич, Позаненко 2013] становится нецелесообразным, поскольку межвахтовые приезды домой обходятся слишком дорого. Отходники встретились нам только в костромских населенных пунктах, откуда выбраться можно хоть и не всегда, но быстрее и, главное, дешевле, так как они ближе к Москве, основному центру притяжения трудовых мигрантов европейской части России.

На биржу труда люди предпочитают не вставать, поскольку в большинстве случаев отмечаться, подтверждая поиск работы, по месту жительства невозможно, нужно дважды в месяц ездить в районный центр занятости, а стоимость поездок существенно превышает величину пособия 6 . Те единицы, которые оформляют пособие по безработице, делают это исключительно ради трудового стажа. Там же, где отмечаться в населенном пункте можно, на биржу встают, но работу не ищут, от предложенных вакансий на стороне (часто далеких и почти всегда низкооплачиваемых) отказываются и продолжают заниматься неоформляемой работой или подработками, позволяющими получать удовлетворяющий доход и не покидать своего сообщества. По истечении срока выплаты пособия они выполняют какуюлибо непродолжительную официально оформленную работу (например, чистят в зимний период прорубь по договору с сельской администрацией) и вновь встают на биржу.

\footnotetext{
6 По тем же обстоятельствам в изолированных населенных пунктах сложилась нетипичная для провинции ситуация с оформлением инвалидности. Обычно в сельской местности и малых городах жители, чтобы получать пенсию, пытаются оформить инвалидность, даже если на это нет объективных медицинских показателей. В труднодоступных деревнях, напротив, есть реальные инвалиды, которым это сделать не удалось, поскольку собирать документы и ездить на врачебно-трудовую экспертную комиссию затруднительно.
} 
Таким образом, большая часть трудоспособных жителей, как правило, не задействована на официальном рынке труда, при этом никто не бедствует и тем более не голодает. Как сказал один из информантов, «никто нигде не работает, и у каждого по две машины стоят во дворе» ${ }^{7}$. Люмпенизированные алкоголики, живущие на пенсию родителей и изредка «подкалымливающие» за выпивку, в таких сообществах встречаются не везде, а где они есть, то их лишь единицы. Вопрос трудоустройства для многих местных жителей решается теневой работой или комбинированием подработок, в основном также теневых. Эти источники заработка частично используются и теми, кто живет на пенсию (в том числе по инвалидности) или официальную зарплату, не говоря уже о пособии по безработице.

Теневая занятость может быть предпринимательского и наемного характера. В первом случае это прием дикоросов в целях дальнейшей сдачи или перепродажи, содержание магазина, пилорамы, гостевого дома для туристов-экстремалов. Во втором случае - работа на лесозаготовках, пилорамах, в арендуемых приезжими охотничьих угодьях, приемщиками дикоросов у пришлых предпринимателей, на турбазах для богатых туристов. Так, в нескольких сотнях километров от мурманского села расположилась вереница турбаз, построенных предпринимателями из областного центра и ориентированных на прием иностранцев и малознакомых с дикой природой жителей мегаполисов, желающих порыбачить в нетронутой северной глуши; селяне нанимаются туда сторожами и снабженцами.

Значительно более распространено комбинирование различных разовых приработков. Показателен пример одинокой средних лет жительницы костромского поселка: она стоит на бирже труда и ездит отмечаться в районный центр, что невыгодно, однако женщина извлекает из этих поездок дополнительную выгоду, заезжая попутно в село, где за оплату ухаживает за пожилой женщиной-инвалидом; кроме этого, она продает грибы и ягоды, вяжет на продажу одежду из шерсти своих овец, а также банные веники, ловит и продает рыбу, возит желающих на своей машине (не имея прав) и перевозит на лодке через реку, во время избирательных кампаний и выборов работает в избирательной комиссии поселкового участка. Способности подобным образом получать средства к существованию в условиях отсутствия работы или мизерных зарплат В.Г. Виноградский назвал «орудиями слабых»: «Эти способности буквально из ничего сотворили сегодня некую самодельную гарантийно-страховую систему, цель которой - физическое и социальное выживание. <...> "Орудия слабых" всегда наготове. Они буквально распылены вокруг социального субъекта, они повсеместны и по причине своей простоты доступны всем - детям, женщинам, старикам» [Виноградский 2002, с. 311]. Он считает, что «орудия слабых» не в состоянии обеспечить высокий уровень благосостояния, а лишь поддерживают их жизнедеятельность. Однако наблюдения показывают, что этот тезис справедлив лишь для тех мест, где невозможна или сильно затруднена присваивающая экономика, дающая относительно высокие доходы при относительно небольших трудозатратах, особенно там, где доступ к природным ресурсам вследствие труднодоступности имеют только местные жители [Калугина, Фадеева 2009, с. 263]. Например, килограмм ягод у приемщиков (в зависимости от региона, фазы сезона и урожайности) стоит от 40 до 120 руб. По словам одной из информанток, опытный сборщик за день может вручную (без помощи

7 Неработающий мужчина, около 40 лет, Коми, август 2013 г. 
комбайна-грабилки, ускоряющего процесс примерно в два раза) собрать до 20 л. ${ }^{8}$ клюквы. Брусника же собирается быстрее и с меньшим количеством сора. Занимаясь сбором лишь время от времени и в одиночку, можно заработать несколько десятков тысяч рублей, а это эквивалент 3-4 среднемесячных провинциальных зарплат. Если же этим интенсивно занимается целая семья весь ягодный сезон (около четырех месяцев), то счет идет уже на сотни тысяч рублей. Грибы (при условии знания мест и урожайного сезона) собираются быстрее ягод, и бывалые грибники могут за один поход принести из леса не одну сотню боровиков. Для некоторых семей сбор дикоросов стал основным, хотя и не единственным, источником заработка, позволяющим безбедно жить весь год.

«Они [семья пенсионеров, каждому из которых около 70 лет] за сезон нам (я посчитала) сдали тонну клюквы. Сами собирают, вдвоем. Брусники и грибов, не знаю, сколько сдавали, черники сдали тысяч на 50 или 60. Конечно, по сравнению с Москвой это, может, и немного, но 200 тысяч семье пенсионеров! Да плюс пенсия! Им не надо платить за жилье, за квартиру. Не надо на транспортные расходы какие-то большие» ${ }^{9}$.

Повсеместно подавляющее большинство мужчин рыбачат, встречаются и женщины-рыбаки, однако основным источником дохода рыба является лишь для части жителей поморских деревень. В остальных местах она ловится преимущественно для себя и родственников, продать ее удается редко, поскольку возможности сбыта ограничены, и покупают рыбу только нерыбачащие старушки и редкие заезжие люди. Охотников меньше, чем рыбаков. Выбор в пользу занятия охотой зависит от населенного пункта - в некоторых из них охотники есть в большинстве домов; охотятся, за редкими исключениями, также преимущественно для себя.

Можно было бы предположить, что архаическая модель жизнеобеспечения живущих природными ресурсами объясняется при помощи концепции моральной экономики Джеймса Скотта - не вводить никаких новшеств, даже самых многообещающих, если это связано хоть с малейшим риском возникновения нищеты и голода [Scott 1976]. Однако люди, обеспечивающие свое существование таким образом, живут не просто выше уровня выживания, а значительно зажиточнее. Они не хотят ничего менять не потому, что боятся рисков, а потому, что их устраивает их образ жизни и хозяйствования. Уровень заработков, возможность самостоятельно обеспечить себя всем необходимым (продуктами питания, дровами, стройматериалами) и сопутствующий свободный образ жизни зачастую оказываются привлекательнее официальной работы, даже если незанятые рабочие места имеются непосредственно в селе.

«В отличие от всех карельских деревень здесь не надо работы, не надо зарплаты. Здесь на рыбе можно жить припеваючи. < .. > Рыба иенная: не какие-нибудь окуни, плотва, щуки. Я тоже был во всех районах, но здесь самое благодатное место. < ...> Ягод здесь столько, что я в жизни столько ягод не видел. <... Если здесь уродится морошка, то столько ее нигде нет, с черникой - то же самое» ${ }^{10}$.

\footnotetext{
8 Один литр (в зависимости от разновидности ягод) соответствует 600-800 граммам.

9 Предпринимательница, около 45 лет, Костромская область, ноябрь 2013 г.

10 Продавец, мужчина, около 50 лет, Карелия, июнь 2013 г.
} 
«К нам почему мужчины неохотно идут работать? Вот представьте: если он работает сторожем, дворником или рабочим, например, ему надо каждый день быть на работе. А мужчинам надо постоянно ездить в лес за дровами, на охоту, на рыбалку» ${ }^{11}$.

\section{Образ жизни}

Пространственная изоляция предопределяет особый образ жизни людей. Большую роль в его формировании играют способы обеспечения себя пропитанием растениеводство, собирательство, рыбалка и охота. Местное население в полной мере использует возможности по своему усмотрению и бесконтрольно пользуется окружающими природными ресурсами.

«Мама рассказывала, что когда селились в этой деревне, говорили: “Будем ли бога-

mы, нет, а сытые будем”. Здесь все есть. Прожить безбедно здесь можно» ${ }^{12}$.

Почти в каждом доме есть ружье (иногда самодельное), причем чаще всего неоформленное. Как правило, участковые об этом знают, но никого не трогают, поскольку понимают, что без ружья людям, живущим лесом, не обойтись. Поэтому приезжая изредка в рейды для выполнения плана по штрафам, они наказывают по мелочам (например, за непривязанных собак), а остального «не замечают».

Изоляция влияет на пищевой рацион, и в этом отношении местные жители существенно больше обычного используют дары природы, что связано не только с наличием такой возможности, но и с осознанием людьми того, что они полностью предоставлены сами себе. Регулярно и в больших количествах на столе представлены экзотические для городского человека яйца диких птиц (чаек, гаг), дичь (лосятина, кабанятина, оленина), ягоды (морошка, вороника) и прочее. В поморских деревнях значительно потребление самой разнообразной, в том числе незнакомой горожанам рыбы (например, пинагоров). Вообще мяса и рыбы потребляется значительно больше, чем в неизолированных деревнях. В поморских деревнях, например, в каждом доме есть огромные промышленные морозильники, в которых круглый год хранятся дичь и рыба, и таких ларей в одном домохозяйстве может насчитываться до 5-6 штук. Их количество, объем и качество являются своеобразным маркером материального благополучия семьи. В рационе жителей пространственно изолированных населенных пунктов ниже доля магазинных продуктов, особенно скоропортящихся и продуктов не первой необходимости, меньше потребляется фруктов и овощей, которые в магазинах представлены скудно. Обычно завоз в магазины осуществляется раз в 1-3 недели, но если населенный пункт отрезан водой, то во время ледостава и ледохода завоз не происходит по 1-2 месяца.

«4 месяиа в году - это вообще, остров такой. Сам себя кормит, поит. Поэтому люди

здесь с запасом живут, потому что иначе можно остаться ни с чем» ${ }^{13}$.

Дороговизна доставки, а иногда и малый ее объем ведут к высоким ценам, которые по отдельным наименованиям могут превышать привычные для горожан

\footnotetext{
11 Директор школы, женщина, около 45 лет, Мурманская область, июнь 2013 г.

12 Специалист администрации, женщина, около 50 лет, Карелия, июнь 2013 г.

13 Фельдшер, женщина, около 45 лет, Костромская область, февраль 2013 г.
} 
в 2-3 раза. Это особенно ощущается в мурманском селе, куда товар доставляется вертолетом (причем предприниматели, пользуясь положением, поднимают цены в сравнении со своими же магазинами в районном центре непропорционально росту себестоимости), поэтому жители стараются самостоятельно завозить все с «большой земли».

В обследованных примезенских населенных пунктах практически у каждой семьи построены по берегам рек одна или чаще несколько избушек, служащих в качестве баз во время рыбалки, охоты и сбора дикоросов. Феномен охотничьих избушек сколь немыслим в средней полосе, на юге и вблизи крупных городов, столь и неотъемлем для жителей тайги, тундры и северных российских побережий. Они есть во всех регионах, на территории которых проводилось исследование, но на Мезени их значимость и количество в расчете на одного жителя наивысшие. Некоторым избушкам более ста лет, другие построены уже в настоящее время: они срублены в полюбившемся месте (если есть желание построиться вблизи уже существующей избушки, необходимо договориться с ее хозяином) и зачастую никак не оформлены.

Интервьюер: «А избушки как решали, где строить?».

Респондент: «Старики ставили раньше, кто как поставил, кому какое место понравилось, так и делай».

Интервьюер: «А потом они никак не оформлялись?».

Респондент: «Нет, но вот отеи мне оставил завещание, что избушка мне переходит».

Интервьюер: «А с точки зрения государства?».

Респондент: “С точки зрения государства их не существует» ${ }^{14}$.

Всем известна принадлежность данных строений; этим обусловлены некоторые ограничения на хозяйственную деятельность - возле чужой избушки, например, нельзя ставить рыболовные сети. Теоретически возможно оформить избушку (такие избы есть), но на деле это весьма затруднительно ${ }^{15}$. С одной стороны, такие строения находятся под защитой закона, с другой, это сопряжено с дополнительными расходами, и, главное, оформленные избушки становятся известны контролирующим инстанциям, представители которых могут специально приезжать на проверку. Также для контролирующих органов владелец такой избушки будет считаться главным подозреваемым при обнаружении на соответствующей территории браконьерских орудий добычи (а здесь практически любые лов и охота формально являются браконьерскими). Избушки принято всегда держать открытыми, чтобы любой путник мог там обогреться и заночевать; обязательно есть печь, дрова, спички, иногда и запас продуктов. Люди не боятся оставлять там ценные вещи: в одной из избушек, например, автор увидел новый лодочный мотор и бензогенератор. По крайней мере, так было до последнего времени, но совсем недавно некоторые избушки стали закрывать. В целом мезенцами это не одобряется.

«Да, у нас бывают такие случаи, когда школьники пошли в поход с ночевкой, а избушка закрыта, дак потом школа ругается на тех, чви избушки» ${ }^{16}$.

\footnotetext{
14 Депутат сельского поселения, женщина, около 55 лет, Архангельская область, август 2013 г.

15 Оформленные избушки наносятся на карты и помечаются закрашенным прямоугольником и словом «изба» (см. двухкилометровую карту любого северного региона).

16 Студентка ССУЗа, 18 лет, Архангельская область, сентябрь 2014 г. (постэкспедиционное интервью в социальной сети).
} 
Владелец одной из избушек, впервые закрыв ее, в следующий приезд обнаружил на ней нанесенную углем надпись: «Еще раз закроешь - сожжем». Закрытие части избушек на замок связано с тем, что недавно была введена в строй хоть и не асфальтированная, но круглогодичная автомобильная дорога на Архангельск, повысившая транспортную доступность Мезени. На доступность исследованных населенных пунктов наземным транспортом это не повлияло, но до самой реки со стороны Архангельска теперь добраться гораздо проще, а там уже можно спустить на воду моторную лодку. Но, в сущности, замки бесполезны, поскольку их можно сбить, впрочем, информанты пока не отмечают случаев кражи или неуважительного отношения к чужим избушкам. Этого нельзя сказать о неизолированных сообществах: в пригородном Сыктывдинском районе Коми местные жители жалуются, что приезжие (в основном, отдыхающие из Сыктывкара) оставляют в избушках беспорядок, грязную посуду и даже могут что-то украсть.

Личные подсобные хозяйства (как минимум огороды) в изолированных населенных пунктах есть у всех, что для российской деревни является нормой. Исследователи многократно писали о том, что рентабельность личных подсобных хозяйств зависит от наличия в селе или в непосредственной близости от него сельхозпредприятия, которое готово оказывать местным жителям различные сельскохозяйственные услуги, продавать им свою продукцию по низким ценам (наибольшее значение имеют корма) и закрывать глаза на «несунов», пользование техникой в личных целях и прочую нелегальную эксплуатацию ресурсов [Родионова 1999; Никулин 2002; Меtzo 2006; Фадеева 2012]. Если, например, для вспашки огорода можно нанять соседа, у которого есть трактор (у некоторых жителей еще сохраняется и поддерживается техника, оставшаяся от обанкротившегося предприятия), то уже для содержания скота колхозные корма часто имеют решающее значение. Так, в одном костромском селе, где еще существует крошечный СПК, в домохозяйствах сохраняется нехарактерно большое для Нечерноземья поголовье сельскохозяйственной животных: на одного постоянного жителя (всего их более 200) приходится чуть менее двух птиц и одной головы скота, не считая кроликов и пчелосемей. В обследованных костромских лесопунктах скот и птица тоже есть, но в расчете на душу населения значительно меньше. Примечательно, что меньше сельхозживотных и в неизолированных селах тех же районов, где еще остались свои сельхозпредприятия. Что же касается неизолированных населенных пунктов, в которых сельхозпредприятия уже исчезли, то там зачастую жители и вовсе ограничиваются огородами. При этом в упомянутом селе огороды значительно больше, а у некоторых семей даже сохранились личные картофельные поля за пределами села. По всей видимости, к ведению личного подсобного хозяйства там подходят основательнее, чем в деревнях, стоящих на трассе, откуда удобно ездить на работу в районный центр. В то же время на Мезени, где почти не осталось сельхозпредприятий, скота держат много, и местные жители утверждают, что самостоятельно заготавливаемого сена хватает $^{17}$ и корма закупать не нужно (правда, на местных подворьях свиньи

17 С реки хорошо видны обширные аккуратные покосы на окружающих деревни холмах. Это сильно влияет на визуальное восприятие деревень и окрестностей сторонним наблюдателем, оставляя впечатление жилых и благополучных мест. 
и птица, которых сеном не прокормить, отсутствуют). Для европейской части России Мезень необычна еще и тем, что по ее берегам по-прежнему держат лошадей: в некоторых деревнях лошадь есть в каждом дворе, что при этом не исключает наличия снегохода, а иногда и трактора.

«Без ломадей здесь никак. Надо и сено привезти, и дрова привезти, и навоз вывезти, пахать, сенокос» ${ }^{18}$.

Мурманское село отличается тем, что основной скотиной, в том числе и личной, там по-прежнему остается северный олень, и если у кооператива насчитывается чуть более десяти тысяч голов, то у жителей - до нескольких десятков. При этом от владельцев практически не требуется усилий по уходу за животными: 8-9 месяцев в году олени пасутся в тундре самостоятельно вместе с кооперативным стадом, в остальное время ими занимаются сотрудники кооператива.

Практически у каждого домохозяйства есть соответствующая местным условиям техника - машины высокой проходимости (обычно «Нивы» и УАЗики) и снегоходы, а если деревня стоит на воде, то и лодки. В Мурманской области есть самодельные сани и волокуши, а также частные гусеничные вездеходы. В ходу и более привычный транспорт: на волокушах местные жители привозят старые, бывшие в употреблении машины, купленные на «большой земле» за бесценок: отремонтировав, они используют их исключительно для передвижения по селу, поскольку никуда дальше аэропорта или сельской свалки доехать невозможно. Наличием соответствующей условиям техники обусловлен тот факт, что изоляция извне существеннее изоляции изнутри: местным проще выбраться на «большую землю», чем сторонним людям попасть сюда. Официального общественного транспорта в большинстве обследованных населенных пунктов нет, но кое-где он частично компенсируется неофициальным, варьирующим от места к месту: где-то курсируют неформальные маршрутки-«буханки», где-то пассажиров негласно за вознаграждение берут водители почтовых машин или летящие с турбаз вертолеты. В одном поселении сельская администрация силами местного жителя организовала еженедельные бесплатные рейсы «вахтовки» (большую часть года это единственный транспорт, который может проехать в поселок).

«Отсюда проще улететь [чем сюда]. <..> Летали всяко. И с покойниками летали,

и с грузом, запрессованный так, что вообще не мог с места сдвинуться» ${ }^{19}$.

Мобильной связи во многих местах нет, а стационарные телефоны есть лишь в нескольких домах. В этом отношении местных жителей выручают таксофоны, которые теперь установлены во всех населенных пунктах страны. В одной из поморских деревень, например, автор ежедневно наблюдал очередь к таксофону, правда, работают они не везде, и не везде продаются таксофонные карточки. При этом телевизоры есть почти у всех (очень распространены спутниковые тарелки), интернет - у многих. Таким образом, к изоляции информационной пространственная изоляция не ведет.

18 Пенсионерка, около 60 лет, Коми, август 2013 г.

19 Дизелист, мужчина, около 50 лет, Мурманская область, июнь 2013 г. 


\section{Сплоченность населения}

В пространственно изолированных селах очень высок уровень доверия внутри сообществ. Для внешнего наблюдателя об этом сразу сигнализирует тот факт, что ни в одном из населенных пунктов не встретилось глухих заборов (забора либо нет, либо он низкий и ничего не скрывающий). Такая закономерность вообще характерна для периферийных северных деревень, но в изолированных она практически не знает исключений. Это свидетельствует о том, что здесь все «свои», ведь, как отмечает В.Л. Каганский, огораживание участков отнюдь не символическими заборами указывает на то, что «ландшафт переполнен посторонними» [Каганский 2013, с. 19]. Уходя, люди оставляют открытыми не только охотничьи избушки, но и дома, они лишь приставляют к входной двери какой-либо предмет (чаще всего метлу), чтобы показать, что дома никого нет.

«Я не закрываю, потому что я сама никогда ни к кому не пойду и не возьму. И всегда верю людям, что никто ко мне не придет, без спроса не возьмет. У меня палочка стоит на двери и все» ${ }^{20}$.

Раньше это было характерно для Севера вообще, но в последнее время подобные беспечность и доверчивость в неизолированных северных селах встречаются все реже.

«Здесь если ушел, и дом не закрыл, никто не войдет, а там [в ближайшей деревне на трассе] даже на замках сидят. Потому что там все-таки дорога, люди боятся, а здесь любой новый человек на виду. Вы, может, никого не видели, а уже все знают, что Вы здесь сидите» ${ }^{21}$.

Ни в средней полосе, ни тем более на густонаселенном юге России такой традиции нет. В южных регионах уровень доверия может быть высок среди родственников, соседей и близких знакомых, но в масштабах всего села - крайне редко. В этом отношении показательна описанная О.П. Фадеевой ситуация, случившаяся в одной из кубанских станиц: отъезд мужа на заработки потребовал «<..> принятия специальных мер для безопасности остающихся жены и детей. $<\ldots>$ Бабушки договорились каждую ночь по очереди приходить ночевать в дом молодых, чтобы не оставлять одних молодую женщину с двумя маленькими детьми» [Фадеева 2002, с. 183-184]. В ходе исследований отходничества, проводившихся при участии автора преимущественно в средней полосе и на Севере [Плюснин, Заусаева, Жидкевич, Позаненко 2013], ничего подобного зафиксировано не было.

В пространственно изолированных сообществах практически не бывает воровства, за исключением мелочного, исходящего от редких люмпенизированных алкоголиков, которые могут, например, стащить несколько поленьев.

Мужчина: «Вот мотоцикл сломался по дороге, бензин кончился или че, так бросили.

Он месяи будет стоять, его никто не тронет».

Женщина: "А [в районном центре] уже, на той стороне, на правобережье, там уже все, там ниче не оставишь. Мы жили в Самарской области. У меня свекровь,

\footnotetext{
20 Пенсионерка, бывшая председатель колхоза, 71 год, Карелия, август 2013 г.

21

Фельдшер, женщина, около 45 лет, Костромская область, февраль 2013 г.
} 
Царствие небесное, на ночь хлев закрывала, потому что поросят вытаскивали. Сено скосят и ждут, пока высохнет, потом сгребут. А если не досохло, то привозили домой и во дворе раскидывали, потому что там украдут» ${ }^{22}$.

Если вор станет известен, то в своем сообществе, где жизнь регламентируется внутренними общинными правилами, он станет изгоем ${ }^{23}$, поэтому замечены в воровстве приезжие; сейчас это случается редко, однако в 1990-е гг., по словам информантов, по глубинке ездили многочисленные воры-гастролеры, в одиночку и группами: от них страдали и пространственно изолированные деревни, стоящие на транзитных речных путях, в те годы с многих лодок были сняты моторы.

В неизолированной сельской местности люди обычно жалуются, что раньше жили дружно, а теперь разобщились, деньги стали мерилом всего, взаимопомощь коммерциализировалась, а совместное проведение досуга заменилось телевизорами и компьютерами ${ }^{24}$. Перелом случился в 1990-е гг.: домохозяйства стали конфликтовать, а потом и вовсе атомизировались. Кризисные явления, с одной стороны, интенсифицировали взаимную поддержку на уровне внутри- и, в меньшей степени, межсемейных сетей [Фадеева 1999; Штейнберг 1999], но, с другой стороны, они породили множество конфликтов, для которых раньше не было поводов. Борьба за ресурсы, стремительно сокращающиеся рабочие места, сбыт и другие возможности неформального заработка (одним словом, конкуренция) привели к тому, что сплоченность сообщества в восприятии его членов резко пошла на убыль. В пространственно изолированных сообществах подобные настроения выражены слабее, а подчас и вовсе отсутствуют.

Респондент: «Просто здесь у нас место, видимо, такое, что люди хорошо здесь жили, дружно. Это даже и раньше было. Я тебе говорю, что не только вот щас, в последнее время, потому что нас уже, можно сказать, бросили. < .. > Из-за этого, может, и выживаем еще. Держимся друг за друга».

Интервьюер: «Где мы ни бывали, почти всегда говорят, что с развалом Советского Союза гораздо менее дружно стали люди жить. Здесь этого нет?».

Респондент: «У нас почти незаметно это было. Почти незаметно. $<\ldots>$ Так вот и велось по жизни. Как раньше народ приветливый был, и помогали друг другу, так uщ̧ac» ${ }^{25}$.

\footnotetext{
22 Чета предпринимателей, около 45 лет, Костромская область, ноябрь 2013 г.
}

23 В этом отношении неубедителен один из эпизодов художественного фильма А. Кончаловского «Белые ночи почтальона Алексея Тряпицына» (2014), изображающего жизнь труднодоступных деревень - в нем односельчанин крадет у главного героя лодочный мотор.

24 Это объяснимо не только тем, что отношения изменились, но и тем, что в советское время отсутствовали обстоятельства, определившие характер современных отношений. В 1970-е и 1980-е гг. в сельской местности стабильно работали колхозы, совхозы и леспромхозы, обеспечивавшие всех работой и примерно одинаковой и приемлемой оплатой труда. Острых проблем с заработком, приобретением жилья, ремонтом, медицинской помощью, образованием, соцкультбытом не было, следовательно, не было нужды в интенсивной взаимной поддержке. В условиях определенности и стабильности взаимная помощь являлась скорее проявлением доброй воли, а не результатом необходимости. Вкупе с совместным проведением досуга, участием в общественных мероприятиях (например, официальные торжества) и коллективных работах (например, сенокос) это оставило в памяти сельчан отпечаток всеобщей взаимопомощи и бескорыстности.

25 Водитель «вахтовки», бывший глава сельского поселения (до его упразднения), 57 лет, Костромская область, ноябрь 2012 г. 
Здесь по-прежнему царят общинные, практически семейные, естественные, по П.А. Кропоткину [Кропоткин 2013], отношения взаимопомощи, во многом делающие сообщество не зависимым от помощи государства.

«Если выехал из [районного ичентра] и долго нет, то обязательно кто-то поедет искать навстречу. Бывает, мы и по трое суток бьемся. Заметет - бела света не видать. <..> Короче, не бросят тебя здесь. Здесь не надо сообщать куда-то, звать МЧС, милицию. Здесь своя тусовка. Поедут и искать будут. Даже если на лодке ушел и нету, поедут искать обязательно. Помощи ждать не от кого. Друг друга выручают все» ${ }^{26}$.

«Взаимность» является ключевым словом для описания этих сообществ взаимодействие местных жителей либо принимает формы выгодного для обеих сторон сотрудничества (бартер, обмен услугами, пусть иногда и отсроченный; денежные отношения встречаются, но менее распространены), либо, по крайней мере, предполагает оказание аналогичной обратной помощи при возникновении соответствующей ситуации [Барсукова 2004; Metzo 2006]. Исключение составляет забота об одиноких и немощных членах сообщества - инвалидах и стариках. Необходимости в полном их содержании нет, поскольку их пенсии хватает, чтобы купить все необходимое и расплатиться с людьми, нанимаемыми для каких-либо хозяйственных работ. Тем не менее некоторая помощь оказывается им во всех смыслах безвозмездно (не только бесплатно, но и не предполагая никакой взаимности). Что касается немногочисленных опустившихся алкоголиков, то масштабной помощи им не оказывают, хотя относятся к ним обычно снисходительно, умереть с голода не дают и иногда предлагают подработать [Полани 1999].

В отношении сплоченности важно указать на еще один момент. Как отмечает Ю.М. Плюснин, среди неизолированных населенных пунктов давно и естественно сформировавшиеся сообщества старых сел и деревень значительно дружнее и сплоченнее сообществ относительно молодых поселков, искусственно созданных вокруг какого-либо производства, совхоза или леспромхоза [Плюснин 2008]. В пространственно изолированных сообществах такой зависимости не наблюдается: по всей видимости, фактор изоляции оказывается сильнее фактора кровного родства, свойств $а$ и соседства в течение многих поколений.

\section{Самодостаточность сообществ}

Уровень самодостаточности сообщества тесно связан со стратегиями получения средств к существованию и со сплоченностью населения. Охарактеризованный выше набор способов получения средств к существованию свидетельствует о том, что жители пространственно изолированных сообществ приспособлены к автономной жизни [Russell, Harris 2001]. Как можно видеть, во многом это обеспечивается доступностью природных ресурсов [Кулясова, Овчинников 2014, с. 108-109]. Важно отметить, что эксплуатация природных ресурсов, несмотря на формально браконьерский характер, не приводит к их истощению. Это объясняется как малочисленностью населения, так и тем, что местные жители осознают свою 
зависимость от природы и не обращаются с ней хищнически, что резко отличает их от заезжих охотников и рыболовов.

«В восьми километрах была точка вояк. < ..> Туда дорога ведет. По ней эти туристы-охотники ездят. Однажды иельй мешок рябчиков оставили гнить» ${ }^{27}$.

«Москвичи идут такие: глухарь летит - бух! Он даже не подойдет. Убил, дальше пошел» ${ }^{28}$.

Важно и то, что органы, отвечающие за законность использования природных богатств, практически не добираются до пространственно изолированных сел ${ }^{29}$. Значительную активность проявляет лишь рыбнадзор, инспектор которого - самый въедливый и страшный представитель государства и злейший враг всех рыбаков, а значит, и практически всех жителей пространственно изолированных деревень, и несмотря на то, что рейды эпизодичны, рыбаки стараются следить за продвижением инспекторов и оповещать друг друга (из-за конфликта интересов он никогда не бывает местным жителем $)^{30}$. Рыбнадзор приезжает, как минимум, из районного центра, а часто даже из другого региона (например, архангельскую часть Мезени инспектируют люди из Коми, а карельские поморские деревни из Архангельской области). Негативное влияние деятельности контролирующих инстанций на самодостаточность сообществ убедительно показано В.Р. Цылевым, сравнившим жизненные пути двух сельских населенных пунктов Мурманской области, изолированного и неизолированного. Он заключает, что труднодоступность и, соответственно, изоляция от контролирующих органов выводят жителей на самообеспечение, основанное в первую очередь на формально нелегальном пользовании окружающими природными ресурсами [Цылев 2015]. Для жителей неизолированного села такие возможности отсутствуют, поскольку контроль налажен, а получить официальную квоту на промышленный лов рыбы практически нереально, поэтому, живя в окружении богатейших природных ресурсов, местные жители не могут ими пользоваться, хотя делали это прежде в течение нескольких столетий. В результате в условиях возникшего в постсоветский период острого дефицита рабочих мест село стремительно депопулирует.

Таким образом, самодостаточность изолированных сообществ во многом держится на экономике, считающейся государством теневой. Почему в таком случае система остается в равновесии? Этому способствуют следующие обстоятельства. Представляется, что теневая экономика возникает не из-за излишней зарегулированности [Де Сото 1995], а вследствие того, что регулирование зачастую исходно не адекватно естественным реалиям жизни, т.е. с точки зрения сообществ действие контролирующих инстанций не излишне, а в принципе ошибочно [Вагин 1999]. Поэтому появление теневой экономики практически неизбежно для любых российских сельских сообществ: в пространственной изоляции она функционирует в форме присвоения природных богатств, в остальных местах - в фор-

\footnotetext{
27 Предприниматель-рыбак, мужчина, около 50 лет, Карелия, июнь 2013 г.

28 Неработающий мужчина, около 45 лет, Костромская область, ноябрь 2013 г.

29 Это же можно сказать и о представителях прочих всевозможных контролирующих инстанций, допекающих сельскую местность регулярными проверками и невыполнимыми требованиями.

30 Этим обусловлена еще одна неправдоподобность фабулы упомянутого фильма «Белые ночи почтальона Алексея Тряпицына», так как в нем показано, что инспектором рыбнадзора работает жительница деревни. Не говоря уже о том, что женщине едва ли случится работать в этой должности.
} 
ме неоформленного отходничества, гаражной экономики [Селеев, Павлов 2016] и прочего. Неестественность регулирования в свою очередь компенсируется тем, что государство во многом игнорирует формально незаконные практики. Последнее может быть объяснено с помощью концепции моральной экономики крестьянства Джеймса Скотта [Scott 1976], если рассматривать государство как помещика (патрона), а сельских жителей - как крестьян: государство оставило селян без помощи и, признавая за ними право на выживание, не пресекает морально оправданное неповиновение. В случае изолированных деревень еще одним объяснением такого поведения государства может быть банальная чрезмерность издержек контроля.

Переходя ко второму фактору самодостаточности - сплоченности населения, - нужно отметить, что из высокого уровня сплоченности, о котором уже говорилось выше, следует развитая самоорганизация [Felt, Sinclair 1992; Gucher 2013; Mendas 2016]. Ее проявления встречаются во всех обследованных населенных пунктах, а в большинстве из них они носят систематический характер. Не надеясь на власть, жители сами решают основные вопросы: намораживание переправы, устройство парома, уборка территории, расчистка просек под ЛЭП, тушение пожаров, укрепление берегов реки, ремонт колодцев и т.д.

«Но они понимают, что, кроме них, больше никто не сделает. Кому дорогу заливать?

Я ее не залью, потому что у меня денег нет. Они и не спрашивают меня, команды не дожидаются» ${ }^{31}$.

Люди сами следят за состоянием дороги: деньги из бюджета и техника на их содержание не выделяются, так как дорог во многих населенных пунктах официально нет, равно как нет и официальных дорог, соединяющих эти села с внешним миром. То же самое можно сказать о состоянии жилищ, так как официально не существуют и некоторые дома. Особенно это характерно для поселков при бывших лесопунктах, где жилье (обычно одноэтажные бараки на несколько квартир) строил и обслуживал не существующий теперь леспромхоз.

«Часть [жилья] в муниципальное перешла, а часть никуда не перешла. Кто-то приватизировал, кто-то нет. Из пенсионеров никто не приватизировал. Это жсилье уже списанное, оно нигде не числится. Они и квартплату не платят. Мы к ЖКХи не относимся. [В районном иеентре] им эта головная боль не нужна» ${ }^{32}$.

Власти изолированные села практически не трогают, не помогая и не мешая им, а функции властей, самоорганизовываясь, выполняют сами жители. Собственные органы местного самоуправления есть лишь в трех населенных пунктах, в остальных - либо специалист администрации, либо депутат, либо староста, а иногда между населением и местной властью и вовсе нет никаких институционализированных связующих звеньев. При этом важно понимать, что главы, где они есть, в первую очередь являются местными жителями, а не управленцами, встроенными в систему государственного и муниципального управления. Бюджеты, которыми они распоряжаются, минимальны, а институционализированные рычаги управления очень слабы - это в большей степени касается специалистов и тем более депутатов и старост. В неизолированных селах, не имеющих своих органов местного самоуправления, специалисты администрации обычно ограничиваются

\footnotetext{
31 Глава сельского поселения, на территории которого находится изолированный поселок, женщина, около 50 лет, Костромская область, ноябрь 2012 г.

32 Фельдшер, женщина, около 45 лет, Костромская область, февраль 2013 г.
} 
выдачей справок, а депутаты и старосты (где они есть) и вовсе ничего не делают [Позаненко 2015]. В пространственно изолированных селах такие люди проявляют активность значительно чаще, при этом их инициативы обычно реализуются при поддержке и активном участии остальных жителей, что, по сути, является проявлением самоорганизации. Например, в мурманском селе главным инициатором и координатором благоустройства является женсовет, возникший стихийно и объединивший многочисленных активных женщин. По его решению в селе было введено самообложение, вырученные средства от которого тратятся на вывоз мусора (в селе очень чисто), мелкое строительство (например, возведение кладбищенской ограды) и другие нужды. Даже специалист администрации был утвержден центром после того, как его предложил женсовет.

Судя по наблюдениям, развитие самоорганизации положительно связано со степенью изоляции. Косвенные подтверждения данного вывода можно увидеть и в литературе. Представляется, что Г.В. Тюрин, социальный технолог, специализирующийся на развитии деревень, простимулировавший самоорганизацию на Мезени и Пинеге [Тюрин 2007; Пищикова 2008], добился этого именно потому, что там для нее были предпосылки - единые сплоченные сообщества и труднодоступность. На Пинеге есть и другие примеры эффективной самоорганизации, выраженной в деятельности сельского территориального общественного самоуправления (ТОСа) [Миронова 2010]. Причем если «поднятый» Г.В. Тюриным ТОС в слабо изолированной деревне в итоге закрылся, то описанные Н.И. Мироновой ТОСы в деревнях более труднодоступных продолжают успешно развиваться. Стоит также добавить, что на эту связь, хоть и не прямо, указывает Т.Г. Нефедова, полагающая, что сильнее всего в европейской части России самоорганизация развита в селах нечерноземной периферии и некоторых кавказских республик [Нефедова 2003], т.е. именно там, где выше всего доля труднодоступных сел.

Одномоментно вывести сообщество из самодостаточности может такое событие, как закрытие школы. Местные жители не в состоянии обучать детей на дому, а отправлять их к родственникам или в интернат решаются немногие, не говоря уже о том, что интернаты есть далеко не во всех районных центрах. Хотя, например, без официальной медицины люди вполне справляются - на месте, в лучшем случае, есть только фельдшерско-акушерский пункт, скорая в большинство обследованных населенных пунктов не выезжает, часто она даже гипотетически не может проехать. И вообще, некоторые местные жители утверждают, что болезни приходят только с приезжими.

«Здесь никто не болеет, если никто извне не приезжает. Раньше были Лыковы, знаешь. И здесь точно так же. Начинают приезжать - и пошла инфекиия, и гуляет. Прошли январские праздники, народу много, привезли инфекции - ну все, январь болеем. Переболели все, всех перебрало, и у нас успокоилось, затишье» ${ }^{33}$.

Является ли самодостаточность залогом успешного будущего изолированных сел и деревень? Современная российская провинция (по крайней мере, на уровне нарратива) живет преимущественно прошлым, ностальгирует по нему и мало надеется на будущее [Бредникова 2013, с. 48]. Эти настроения присутствуют и в пространственно изолированных населенных пунктах, но в целом их жители

33 Фельдшер, женщина, около 45 лет, Костромская область, февраль 2013 г. 
настроены оптимистичнее, зачастую даже считают, что живут хорошо, и верят, что их места ждет не вымирание, а полноценная жизнь.

«Люди стали рожать. Кто-то второго, кто-то третьего. Женщины не боятся.

$<\ldots>$ Ничего, живем. Уезжать не собираемся» ${ }^{34}$.

Важно, что люди осознают преимущества труднодоступности и в большинстве своем считают изоляцию и отсутствие дорог благом, обеспечивающим им практически полную свободу и возможность вести устраивающий их образ жизни в спокойном, понятном мире. Общинные отношения гарантируют высокий уровень взаимопомощи и самоорганизации, которые позволяют эффективно решать проблемы. Местные жители дорожат такими отношениями и не хотят их лишаться.

Респондент: «Будем надеяться, село наше не вымрет, а будет жить тихонечко.

Надо, чтоб жило-то. Привыкли уже здесь, сами по себе. Отдельная типа республичка. Я лично против того, чтоб дорога тут была» ${ }^{35}$.

Интервьюер: «А если был мост через реку и асфальт, было бы хорошо?».

Респондент: «Не нужен! Здесь все пропадет!» ${ }^{36}$.

Целыми семьями отсюда уезжают редко: взрослые и тем более пенсионеры привязаны к своему месту жительства и родному сообществу. Те немногие, кто хотел бы переехать - почти исключительно женщины, поскольку мужчины не представляют жизни без леса и реки. Даже дети часто связывают свое будущее с малой родиной и, по крайней мере, на словах, собираются после получения профессионального образования вернуться. Некоторые, хоть и меньшинство, действительно возвращаются.

Как, однако, замечает Т.И. Трошина, общинная деятельность в изолированных селах носит социальный, но не экономический характер, и это не позволяет им развиваться [Трошина 2016], т.е. вопрос о будущем труднодосягаемых населенных пунктов остается открытым. Но, так или иначе, настоящее у многих из них есть, и сообщества, находящиеся в значительной пространственной изоляции, как показывают наблюдения, зачастую оказываются устойчивее аналогичных неизолированных сельских сообществ [Позаненко 2017].

\section{Заключение}

Исследование социальной структуры пространственно изолированных локальных сельских сообществ показывает, что труднодоступность дает им ряд преимуществ, которых лишены их неизолированные аналоги. Представляется, что основным из них является отсутствие взаимодействия с институтами публичной власти - контролирующими и опекающими. Отсутствие государственного контроля позволяет населению пользоваться наиболее доступными, эффективными и благоприятными для себя (и для сообщества) способами получения средств к существованию. Если в обычных условиях массовое банкротство сельскохозяйственных предприятий

\footnotetext{
34 Метеоролог, женщина, 62 года, Мурманская область, июнь 2013 г.

35 Связист, мужчина, около 45 лет, Мурманская область, июль 2013 г.

36 Мужчина (из четы предпринимателей), около 45 лет, Костромская область, ноябрь 2013 г.
} 
и леспромхозов на нечерноземной периферии приводит к полному или частичному вымыванию из села трудоспособного населения, то альтернативой этому процессу (при условии слабого контроля) может стать освоение природных богатств [Фадеева 2012, с. 23], чем и пользуются обитатели изолированных сообществ. Поэтому, несмотря на отсутствие сколь-либо развитого доступного официального рынка труда, люди имеют возможность зарабатывать (в теневом секторе) и живут в относительном достатке. Отсутствие же государственной опеки прямо стимулирует членов сообщества к взаимной поддержке и самоорганизации [Барсукова 2004; Кропоткин 2013], что позволяет им оперативно и эффективно решать как частные, так и общие вопросы, а не перекладывать ответственность за свое благополучие на власть. Перечисленные особенности труднодоступных сообществ положительно влияют на их самодостаточность и, как следствие, на их жизнеспособность и устойчивость.

\section{Литература}

Аверкиева К.В. (2016) Рынки труда и роль отходничества в занятости сельских жителей российского Нечерноземья // Известия РАН. Серия географическая. № 1. С. 25-37.

Барсукова С.Ю. (2004) Реципрокные взаимодействия. Сущность, функции, специфика // Социологические исследования. № 9. С. 20-29.

Бредникова О. (2013) Деревня умерла? Да здравствует деревня! (еще раз к вопросу о различиях города и деревни) // Богданова Е., Бредникова О. (ред.) Вдали от городов. Жизнь постсоветской деревни. СПб.: Алетейя. С. 28-59.

Вагин В. (1999) Неформальная экономика и «совокупное жилье» горожан России // Шанин Т. (ред.) Неформальная экономика. Россия и мир. М.: Логос. С. 156-172.

Виноградский В.Г. (2002) «Орудия слабых»: экономика крестьянской повседневности // Шанин Т., Никулин А., Данилов В. (ред.) Рефлексивное крестьяноведение: Десятилетие исследований сельской России. М.: МВШСЭН, РОССПЭН. С. 294-313.

Де Сото Э. (1995) Иной путь. Невидимая революция в третьем мире. M.: Catallaху.

Ильин В.И. (2010) Российская глубинка в социальной структуре России // Журнал социологии и социальной антропологии. № 4. С. 25-47.

Каганский В.Л. (2011) Исследование российского культурного ландшафта как целого и некоторые его результаты // Международный журнал исследований культуры. № 4(5). С. 26-37.

Каганский В.Л. (2013) Как устроена Россия? Портрет культурного ландшафта. М.: Стрелка пресс.

Калугина З.И., Фадеева О.П. (2009) Российская деревня в лабиринте реформ: социологические зарисовки. Новосибирск: ИЭОПП СО РАН.

Кропоткин П.А. (2013) Взаимная помощь среди животных и людей как двигатель прогресca. М.: ЛИБРОКОМ.

Кулясова А.А., Овчинников А.В. (2014) Возможности, проблемы и опыт устойчивого сельского развития // Овчаров А.В., Михалюк Н.С., Лукиенко Л.В., Петрова Г.Д., Ермаков Д.С. (ред.) Гуманитарные и естественнонаучные факторы решения экологических проблем и устойчивого развития. Часть 1. Новомосковск: Новомосковский филиал УРАО. С. 104-110.

Миронова Н.И. (2010) Социокультурные процессы формирования местных сообществ (по результатам исследования в пилотных регионах) // Резник Ю.М., Миронова Н.И. (ред.) Местные сообщества: проблемы социокультурного развития: Сборник статей. М.: Независимый институт гражданского общества. С. 136-179.

Морозова Т.В. (2008) Сельские сообщества России в региональном измерении. М.: МОНФ; Центр социального анализа и реконструкции; Институт экономики КарНЦ РАН. 
Нефедова Т.Г. (2003) Социально-экономическая и пространственная самоорганизация в сельской местности // Мир России. № 3. С. 35-61.

Нефедова Т.Г. (2008) Прошлое, настоящее и будущее староосвоенных периферийных районов Нечерноземья (на примере Костромской области) // Вопросы государственного и муниципального управления. № 1. С. 165-183.

Никулин А.М. (2002) Кубанский колхоз - в холдинг или асьенду? // Социологические исследования. № 1. С. 41-50.

Никулин А.М., Никулина Е.С. (2015) Мошинский куст: ветви жизнедеятельности северной сельской местности // Никулин А.М., Пугачева М.Г., Шанин Т. (ред.) Крестьяноведение: Теория. История. Современность. Ученые записки. Вып. 10. М.: Дело. С. 274-294.

Пищикова Е. (2008) Сельский мир. Деревенское самоуправление: искусственное и естественное // Русская жизнь, 24 апреля 2008 // http://www.rulife.ru/mode/article/670

Плюснин Ю.М. (2008) Факторы развития местного самоуправления. Оценка значения изоляции и изоляционизма // Вопросы государственного и муниципального управления. № 3. С. 38-50.

Плюснин Ю.М., Заусаева Я.Д., Жидкевич Н.Н., Позаненко А.А. (2013) Отходники. М.: Новый хронограф.

Позаненко А.А. (2015) Последствия укрупнения сельских поселений: взгляд снизу // Вопросы государственного и муниципального управления. № 1. С. 168-184.

Позаненко А.А. (2017) Пространственная изоляция и устойчивость локальных сообществ: к развитию существующих подходов // Вестник Томского государственного университета. Философия. Социология. Политология. № 4. С. 244-255.

Полани К. (1999) О вере в экономический детерминизм // Шанин Т. (ред.) Неформальная экономика. Россия и мир. М.: Логос. С. 505-513.

Родионова Г. (1999) Современное сельскохозяйственное предприятие и стратегии выживания сельских сообществ: симбиоз функций и величин // Шанин Т. (ред.) Неформальная экономика: Россия и мир. М.: Логос. С. 219-226.

Родоман Б.Б. (2006) Экологическая специализация России в глобализирующемся мире (проект нестандартного решения) // Общественные науки и современность. № 2. C. $78-89$.

Селеев С.С., Павлов А.Б. (2016) Гаражники. М.: Страна Оз.

Трошина Т.И. (2016) Стратегии и практики коллективного самосохранения населения северной деревни: исторический опыт и современные реалии // Экономические и социальные перемены: факты, тенденции, прогноз. № 2. С. 94-113.

Тюрин Г.В. (2007) Опыт возрождения русских деревень. М.: Поколение.

Фадеева О.П. (1999) Межсемейная сеть: механизмы взаимоподдержки в российском селе // Шанин Т. (ред.) Неформальная экономика: Россия и мир. М.: Логос. С. 183-218.

Фадеева О.П. (2002) Способы адаптации сельских семей к изменениям экономической среды (по результатам бюджетных обследований на Кубани и в Поволжье) // Шанин Т., Никулин А., Данилов В. (ред.) Рефлексивное крестьяноведение: Десятилетие исследований сельской России. М.: МВШСЭН, РОССПЭН. С. 161-215.

Фадеева О.П. (2012) Трансформация хозяйственных укладов и потенциал самоорганизации сельских сообществ // Никулин А.М. (ред.) Вторая Россия: дифференциация и самоорганизация: сборник научных статей. М.: Дело. С. 15-43.

Цылев В.Р. (2015) Особенности социокультурной адаптации населения малых поселков Кольского Севера в условиях социально-экономических преобразований // В мире научных открытий. № 7.5 (67). С. 1899-1927.

Штейнберг И.Е. (1999) Русское чудо: локальные и семейные сети взаимоподдержки и их трансформация // // Шанин Т. (ред.) Неформальная экономика: Россия и мир. М.: Логос. С. 227-239.

Felt L.F., Sinclair P.R. (1992) “Everyone Does It”: Unpaid Work in a Rural Peripheral Region // Work Employment \& Society, vol. 6, no 1, pp. 43-64.

Gucher C. (2013) Formes et Fondements des Relations entre Générations Hors de la Sphère Familiale: La Spécificité du Milieu Rural Isolé // Retraite et Société, no 64(1), pp. 85-105.

Mendas Zr.A. (2016) Exploring Resistance in Rural and Remote Island Communities // Journal of Organizational Ethnography, no 5, pp. 2-12. 
Metzo K.R. (2006) Exchange in Buriatia: Mutual Support, Indebtedness, and Kinship // Ethnology, vol. 45, no 4, pp. 287-303.

Russell K.C., Harris Ch. (2001) Dimensions of Community Autonomy in Timber Towns in the Inland Norhwest // Society and Natural Resources, vol. 14, no 1, pp. 21-38.

Scott J.C. (1976) The Moral Economy of the Peasant. Rebellion and Subsistence in Southeast Asia. New Haven and London: Yale University Press.

Sherman J. (2006) Coping with Rural Poverty: Economic Survival and Moral Capital in Rural America // Social Forces, vol. 85, no 2, pp. 891-913.

\title{
"A Kinda Separate Little Republic": Structural Specifics of Spatially Isolated Local Rural Communities
}

\author{
A. POZANENKO*
}

\begin{abstract}
*Artemy Pozanenko - Analyst, Project and Educational Laboratory for Municipal Administration, National Research University Higher School of Economics; Lecturer, Department of Local Administration, School of Public Administration, Faculty of Social Sciences, National Research University "Higher School of Economics". Address: 20, Myasnitskaya St., Moscow, 101000, Russian Federation. E-mail: apozanenko@hse.ru
\end{abstract}

Citation: Pozanenko A. (2018) “A Separate Little Republic”: Structural Specifics of Spatially Isolated Local Rural Communities. Mir Rossii, vol. 27, no 4, pp. 31-55 (in Russian). DOI: $10.17323 / 1811-038 X-2018-27-4-31-55$

\begin{abstract}
Existing descriptions of rural communities in the Russian North are based on surveys conducted in non-isolated villages. However, many rural settlements in this area have poor to non-existent transport communication with the outer world. Many villages find themselves spatially isolated and these are poorly represented in the existing research. In this paper, the author fills this gap and identifies the structural specifics of territorially isolated local rural communities. Empirically, the study draws on the records from field research conducted by the author in fifteen villages located in five regions of the European part of Russia. The data were collected using in-depth interviews (63 interviews with local inhabitants and 5 with external experts) and participant observation. The research reveals that isolated communities are structurally different from the more common nonisolated ones. While their demography is similar, the population in isolated communities generally has a higher percentage of children and younger people. The inhabitants of such hard-to-reach villages stand out by their way of life, including subsistence patterns, environmental behavior, and housekeeping. Isolation gives the local population certain advantages. The principal one is the practical absence of any interaction with the authorities, both in terms of control and support. The resulting lack of regulatory oversight
\end{abstract}


and control enables the locals to remain in the shadow economy, and resort to the most available and efficient (and thus beneficial for themselves and the community) means of subsistence, such as the appropriation of local natural resources. In turn, the lack of assistance stimulates mutual support and self-organization, which allows the resolution of private and communal issues quickly and efficiently. In sum, these advantages have a positive impact on self-sufficiency and sustainability of hard-to-reach communities.

Key words: spatial isolation, transport accessibility, Russian rural areas, social structure of rural communities, shadow economy, subsistence economy, local self-government

\section{References}

Averkieva K.V. (2016) Rynki truda i rol' otkhodnichestva v zanyatosti sel'skikh zhitelej rossijskogo Nechernozem'ya [Labor Markets and the Role of "Otkhodnichestvo" in Employment of Rural Residents of Non-Chernozem Zone of Russia]. Izvestiya RAN. Seriya geograficheskaya, no 1, pp. 25-37.

Barsukova S.Yu. (2004) Retsiproknye vzaimodejstviya. Sushchnost', funktsii, spetsifika [Reciprocal Interactions - Essence, Functions, Specifics]. Sotsiologicheskie issledovaniya, no 9, pp. 20-29.

Brednikova O. (2013) Derevnya umerla? Da zdravstvuet derevnya! (eshche raz k voprosu o razlichiyakh goroda i derevni) [The Village Is Dead? Long Live the Village! (Back to the Issue of Differences Between the City and the Village)]. Vdali ot gorodov. Zhizn' postsovetskoi derevni [Away from the Cities. Life of the Post-soviet Village] (eds. Bogdanova E., Brednikova O.). Saint Petersburg: Aleteya, pp. 28-59.

De Soto H. (1995) Inoj put'. Nevidimaya revoliutsiya $v$ tret'em mire [The Other Path. The Invisible Revolution in the Third World]. Moscow: Catallaxy.

Fadeeva O.P. (1999) Mezhsemejnaya set': mekhanizmy vzaimopodderzhki v rossijskom sele [The Interfamily Network: Mutual Aid Mechanisms in Russian Rural Areas]. Neformal'naya ekonomika: Rossiia i mir [Informal Economy: Russia and the World] (ed. Shanin T.). Moscow: Logos, pp. 183-218.

Fadeeva O.P. (2002) Sposoby adaptatsii sel'skikh semej k izmeneniyam ekonomicheskoj sredy (po rezul'tatam byudzhetnykh obsledovanij na Kubani i v Povolzh'e) [Ways for Rural Families to Adapt to Changes in the Economic Environment (Based on the Results of Budget Surveys in Krasnodar Kraj and the Volga Region)]. Refleksivnoe krest'ianovedenie: Desyatiletie issledovanij sel'skoj Rossii [Reflective Peasant Studies: A Decade of Researching Rural Russia] (eds. Shanin T., Nikulin A., Danilov V.). Moscow: MVShSEN, ROSSPEN, pp. 161-215.

Fadeeva O.P. (2012) Transformatsiya khozyajstvennykh ukladov i potentsial samoorganizatsij sel'skikh soobshchestv [Transformation of Economic Patterns and the Potential of Rural Communities' Self-organization]. Vtoraya Rossiya: differentsiatsiya i samoorganizatsiya: sbornik nauchnykh statej [Second Russia: Differentiation and Self-organization. A Collection of Research Articles] (ed. Nikulin A.M.). Moscow: Delo, pp. 15-43.

Felt L.F., Sinclair P.R. (1992) "Everyone Does It": Unpaid Work in a Rural Peripheral Region. Work Employment \& Society, vol. 6, no 1, pp. 43-64.

Gucher C. (2013) Formes et Fondements des Relations entre Générations Hors de la Sphère Familiale: La Spécificité du Milieu Rural Isolé. Retraite et Société, no 64(1), pp. 85-105.

Il'in V.I. (2010) Rossiiskaya glubinka v sotsial'noj stukture Rossii [The Russian Heartland in Social Structure]. Zhurnal sotsiologii i sotsial'noj antropologii, no 4, pp. 25-47.

Kaganskij V.L. (2011) Issledovanie rossijskogo kul'turnogo landshafta kak tselogo i nekotorye ego rezul'taty [A Holistic Investigation of the Russian Cultural Landscape]. Mezhdunarodnyj zhurnal issledovanij kul'tury, no 4(5), pp. 26-37. 
Kaganskij V.L. (2013) Kak ustroena Rossiya? Portret kul'turnogo landshafta [How is Russia Organized? A Portrait of the Cultural Landscape]. Moscow: Strelka press.

Kalugina Z.I, Fadeeva O.P. (2009) Rossiiskaya derevnya v labirinte reform: sotsiologicheskie zarisovki [Russian Village in the Labyrinth of Reforms: Sociological Sketches]. Novosibirsk: Izd-vo IEOPP SO RAN.

Kropotkin P.A. (2013) Vzaimnaya pomoshch'sredi zhivotnykh i liudej kak dvigatel' progressa [Mutual Aid Among Animals and People as a Factor of Evolution]. Moscow: LIBROKOM.

Kulyasova A.A., Ovchinnikov A.V. (2014) Vozmozhnosti, problemy i opyt ustojchivogo sel'skogo razvitiya [The Opportunities, Challenges and Experience of Sustainable Rural Development]. Gumanitarnye $i$ estestvennonauchnye faktory resheniya ekologicheskikh problem $i$ ustojchivogo razvitiya. Chast' 1 [Resolving Ecological Issues and Ensuring Sustainable Development: Humanitarian and Natural Science Drivers. Part 1] (eds. Ovcharov A.V., Mikhalyuk N.S., Lukienko L.V., Petrova G.D., Ermakov D.S.). Novomoskovsk: Novomoskovskii filial URAO, pp. 104-110.

Mendas Zr.A. (2016) Exploring Resistance in Rural and Remote Island Communities. Journal of Organizational Ethnography, no 5, pp. 2-12.

Metzo K.R. (2006) Exchange in Buriatia: Mutual Support, Indebtedness, and Kinship. Ethnology, vol. 45, no 4, pp. 287-303.

Mironova N.I. (2010) Sotsiokul'turnye protsessy formirovaniya mestnykh soobshchestv (po rezul'tatam issledovaniya $\mathrm{v}$ pilotnykh regionakh) [Social-Cultural Processes in Local Communities' Formation (Based on Surveys in Pilot Regions)]. Mestnye soobshchestva: problemy sotsiokul'turnogo razvitiya: Sbornik statej [Local Communities: Problems of Socio-cultural Development. A Collection of Works] (eds. Reznik Yu.M., Mironova N.I.]. Moscow: Nezavisimyj institut grazhdanskogo obshchestva, pp. 136-179.

Morozova T.V. (2008) Sel'skie soobshchestva Rossii v regional'nom izmerenij [Russian Rural Communities in Regional Dimension]. Moscow: MONF; Tsentr sotsial'nogo analiza i rekonstruktsii; Institut ekonomiki KarNTs RAN.

Nefiodova T.G. (2003) Sotsial'no-ekonomicheskaya i prostranstvennaya samoorganizatsiya v sel'skoj mestnosti [Social, Economic and Spatial Self-Organization in Rural Area]. Mir Rossii, no 3, pp. 35-61.

Nefiodova T.G. (2008) Proshloe, nastoyashchee i budushchee staroosvoennykh periferijnykh rajonov Nechernozem'ya (na primere Kostromskli oblasti) [The Past, Present and Future of Long Inhabited Peripheral Non-black Earth Areas (on the Example of the Kostroma Oblast')]. Voprosy gosudarstvennogo i munitsipal'nogo upravleniya, no 1, pp. 165-183.

Nikulin A.M. (2002) Kubanskij kolkhoz - v holding ili as'endu? [A Kuban' Collective Farm Towards Holding or Hacienda?]. Sotsiologicheskie issledovaniya, no 1, pp. 41-50.

Nikulin A.M., Nikulina E.S. (2015) Moshinskij kust: vetvi zhiznedeyatel'nosti severnoj sel'skoj mestnosti [The Moshinsky Bush: Some Branches of Life in the Northern Countryside]. Krest'ianovedenie: Teoriya. Istoriya. Sovremennost'. Uchionye zapiski. Vyp. 10 [Peasant Studies: Theory. History. Modern Times. Proceedings. Issue 10] (eds. Nikulin A.M., Pugachiova M.G., Shanin T.). Moscow: Delo, pp. 274-294.

Pishchikova E. (2008) Sel'skij mir. Derevenskoe samoupravlenie: iskusstvennoe i estestvennoe [The Rural World. Rural Self-government: Artificial and Natural]. Russkaya zhizn', April 24. Available at: http://www.rulife.ru/mode/article/670, accessed 30 June 2018.

Plusnin J.M. (2008) Faktory razvitiya mestnogo samoupravleniya. Otsenka znacheniya izoliatsii i izoliatsionizma [Factors of Local Self-government Development. Evaluating the Importance of Isolation and Isolationism]. Voprosy gosudarstvennogo i munitsipal'nogo upravleniya, no 3, pp. 38-50.

Plusnin J.M., Zausaeva Y.D., Zhidkevich N.N., Pozanenko A.A. (2013) Otkhodniki [Wandering Workers]. Moscow: Novyi Khronograf.

Polanyi K. (1999) O vere v ekonomicheskij determinism [On the Belief in Economic Determinism]. Neformal'naya ekonomika: Rossiia $i$ mir [Informal Economy: Russia and the World] (ed. Shanin T.). Moscow: Logos, pp. 505-513.

Pozanenko A.A. (2015) Posledstviya ukrupneniya sel'skikh poselenij: vzglyad snizu [Implications Resulting from the Enlargement of Rural Settlements: A View from Below]. Voprosy gosudarstvennogo i munitsipal'nogo upravleniya, no 1, pp. 168-184. 
Pozanenko A.A. (2017) Prostranstvennaya izoliatsiya i ustojchivost' lokal'nykh soobshchestv: k razvitiyu sushchestvuyushchikh podkhodov [Territorial Isolation and the Sustainability of Local Communities: Developing the Existing Approaches]. Vestnik Tomskogo gosudarstvennogo universiteta. Filosofiya. Sotsiologiya. Politologiya, no 4, pp. 244-255.

Rodionova G. (1999) Sel'skokhoziaistvennoe predpriyatie i strategii vyzhivaniya sel'skikh soobshchestv [The Modern Agricultural Enterprise and Survival Strategies of Rural Communities: the Symbiosis of Functions and Variables]. Neformal'naya ekonomika: Rossiia i mir [Informal Economy: Russia and the World] (ed. Shanin T.). Moscow: Logos, pp. 219-226.

Rodoman B.B. (2006) Ekologicheskaya spetsializatsiya Rossii v globaliziruyushchemsya mire (proekt nestandartnogo resheniya) [Ecological Specialization of Russia in the Global World]. Obshchestvennye nauki i sovremennost', no 2, pp. 78-89.

Russell K.C., Harris Ch. (2001) Dimensions of Community Autonomy in Timber Towns in the Inland Norhwest. Society and Natural Resources, vol. 14, no 1, pp. 21-38.

Scott J.C. (1976). The Moral Economy of the Peasant. Rebellion and Subsistence in Southeast Asia. New Haven and London: Yale University Press.

Seleev S.S., Pavlov A.B. (2016) Garazhniki [Garazhniks]. Moscow: Strana Oz.

Sherman J. (2006) Coping with Rural Poverty: Economic Survival and Moral Capital in Rural America. Social Forces, vol. 85, no 2, pp. 891-913.

Shteinberg I.E. (1999) Russkoe chudo: lokal'nye i semeinye seti vzaimopodderzhki i ikh transformatsiia [The Russian miracle: local and family networks of mutual aid and their transformation]. Neformal'naya ekonomika: Rossiia i mir [Informal Economy: Russia and the World] (ed. Shanin T.). Moscow: Logos, pp. 227-239.

Troshina T.I. (2016) Strategij i praktiki kollektivnogo samosokhraneniya naseleniya severnoj derevni: istoricheskij opyt i sovremennye realii [Strategies and Practices of Collective Self-Preservation of Population in Northern Villages: Historical Experience and Modern Realities]. Ekonomicheskie i sotsial'nye peremeny: fakty, tendentsii, prognoz, no 2(44), pp. 94-113.

Tsylev V.R. (2015) Osobennosti sotsiokul'turnoj adaptatsii naseleniya malykh poselkov Kol'skogo Severa v usloviyakh sotsial'no-ekonomicheskikh preobrazovanij [The Features of Sociocultural Adaptation of Small Settlements' Population in the Kola North Under Social and Economic Transformations]. V mire nauchnykh otkrytij, no 7.5(67), pp. 1899-1927.

Tyurin G.V. (2007) Opyt vozrozhdeniya russkikh dereven'[Reviving Russian Villages]. Moscow: Pokolenie.

Vagin V. (1999) Neformal'naya ekonomika i «sovokupnoe zhil'e» gorozhan Rossii [Informal Economy and "Aggregate Housing" of Russian City-dwellers]. Neformal'naya ekonomika: Rossiia i mir [Informal Economy: Russia and the World] (ed. Shanin T.). Moscow: Logos, pp. 156-172.

Vinogradskij V.G. (2002) “Orudiya slabykh": ekonomika krest'ianskoj povsednevnosti [“Tools of the Weak": Economics of Everyday Peasant Life]. Refleksivnoe krest'ianovedenie: Desyatiletie issledovanij sel'skoj Rossii [Reflective Peasant Studies: A Decade of Research in Rural Russia] (eds. Shanin T., Nikulin A., Danilov V.). Moscow: MVShSEN, ROSSPEN, pp. 294-313. 